\title{
Perebusan dan penumisan menurunkan kandungan beta karoten dalam wortel
}

\author{
Boiling and sauteing decreased beta carotene levels of carrots
}

Rany Adelina ${ }^{1}$, Noorhamdani $^{2}$, Annasary Mustafa ${ }^{3}$

\begin{abstract}
Background: Carrot is included in high beta carotene vegetable. Therefore, there were limited studies about the effect of cooking on nutrient content. Beta carotene found in carrots are provitamin A carotenoids that have strong antioxidant activity.

Objectives: To determine the amount of beta carotene in carrots treated with two different cooking methods, that were, boiling and sautéing.

Methods: A posttest-only control group design was used for this study. Samples of this study were local carrots varieties, and were selected by quota sampling. The carrots were divided into three groups, with fresh carrots $(n=6)$ as control groups, and boiled carrots $(n=6)$ and sautéed carrots $(n=6)$ as treatment groups. Beta carotenes were extracted using petroleum ether-acetone solvents. They were separated by using column chromatography and measured by spectrophotometer at wave length 450nm. Data collected were analyzed with one way anova followed by post hoc tests duncan, independent t-test, and paired t-test.

Results: The level of beta carotene between fresh carrots, boiled carrots, and sauteed carrots have significant difference with $p=0.013$ (anova, $p<0.05$ ), whereas the level of beta carotene in boiled carrots and sauteed carrots have no significantly difference with $p=0.376$ (independent $t$-test, $p>0.05$ ). However, there is a significant decrease in the level of beta carotene in beginning and end groups from the boiling method with $p=0.027$, and the level of beta carotene in beginning and end groups from the sauteing method have a significant decrease with $p=0.020$ (paired $t$-test, $p<0.05$ ).

Conclusions: Boiling and sauteing decreased beta carotene levels in carrots.
\end{abstract}

KEYWORDS: beta carotene, boiling, carrot, sauteeing

\begin{abstract}
ABSTRAK
Latar belakang: Wortel termasuk dalam sayuran dengan kandungan beta karoten yang tinggi. Walaupun demikian, studi mengenai pengaruh pemasakan terhadap kandungan gizinya masih terbatas. Beta karoten merupakan salah satu jenis karotenoid provitamin A dan berperan sebagai antioksidan kuat yang sangat bermanfaat bagi proses metabolisme yang terjadi pada tubuh manusia.

Tujuan: Untuk mengetahui perbedaan kandungan beta karoten pada wortel yang diolah dengan perebusan dan penumisan.

Metode: Penelitian ini menggunakan metode eksperimental rancangan acak lengkap. Desain penelitian ini adalah the posttest-only control group design. Populasi dan sampelnya adalah wortel varietas lokal. Sampel dipilih dengan cara kuota sampling untuk dibagi dalam tiga kelompok, yaitu wortel mentah $(n=6)$ sebagai kelompok kontrol, sedangkan kelompok perlakuan adalah wortel yang direbus dengan air $(n=6)$ dan wortel yang ditumis dengan minyak goreng $(n=6)$. Variabel yang diukur adalah kandungan beta karoten pada masing-masing kelompok menggunakan kromatografi kolom dan spektrofotometri pada panjang gelombang $450 \mathrm{~nm}$. Analisis data menggunakan oneway anova dilanjutkan dengan post hoc tests duncan, uji independent t-test, dan paired t-test.
\end{abstract}

\footnotetext{
1 Politeknik Kesehatan Kemenkes Malang Jl. Ijen no.77 Malang, Jawa Timur 65145, e-mail: rany.adelina@gmail.com, hp: 085608354436

2 Fakultas Kedokteran Universitas Brawijaya Malang Jl. Veteran, Malang, Jawa Timur 65145

${ }^{3}$ Politeknik Kesehatan Kemenkes Malang Jl. Ijen no.77 Malang, Jawa Timur 65145
} 


\begin{abstract}
Hasil: Kandungan beta karoten antara wortel mentah, direbus, dan ditumis berbeda secara signifikan yaitu $p=0,013$ (anova, $p<0,05$ ). Kandungan beta karoten pada wortel direbus tidak berbeda secara signifikan dengan wortel ditumis yaitu $p=0,376$ (uji independent $t$-test, $p>0,05$ ). Terbukti adanya perbedaan kandungan beta karoten pada kelompok awal dan akhir dari teknik pengolahan perebusan menurun secara signifikan yaitu $p=0,027$, sedangkan kandungan beta karoten awal dan akhir dari teknik pengolahan penumisan menurun secara signifikan yaitu $p=0,020$ (uji paired $t$-test, $p<0,05$ ).

Kesimpulan: Perebusan dan penumisan berpengaruh terhadap penurunan kandungan beta karoten dalam wortel.
\end{abstract}

KATA KUNCI: beta karoten, perebusan, penumisan, wortel

\section{PENDAHULUAN}

Wortel juga merupakan salah satu sumber utama karotenoid provitamin $A$, terutama beta karoten. Beta karoten merupakan provitamin A yang paling aktif. Senyawa ini terdiri atas dua molekul retinol yang saling berkaitan (1). Manfaat beta karoten sama dengan manfaat vitamin A dalam proses fisiologis tubuh ketika beta karoten sudah dikonversikan menjadi retinol/vitamin $\mathrm{A}$ di usus halus $(2,3)$.

Proses pengolahan dapat menyebabkan risiko kehilangan zat-zat gizi. Penurunan kadar gizi bahan pangan akibat pengolahan panas bergantung pada beratnya proses (4). Teknik pengolahan panas yang paling sering dilakukan pada wortel adalah dengan perebusan dan penumisan. Penelitian yang membahas pengaruh pemanasan terhadap zat gizi masih terbatas.

Tujuan penelitian ini adalah untuk membedakan pengaruh penumisan dan perebusan pada wortel terhadap kandungan beta karotennya sehingga dapat menentukan metode memasak wortel yang tepat untuk mendapatkan kandungan beta karoten tertinggi setelah pengolahan. Strategi untuk memecahkan masalah ini antara lain dengan melakukan eksperimen uji kandungan beta karoten pada wortel yang dimasak dengan direbus dan ditumis. Selain itu juga dilengkapi dengan studi literatur yang ada.

\section{BAHAN DAN METODE}

Penelitian ini menggunakan metode eksperimental rancangan acak lengkap. Penelitian ini dilaksanakan pada bulan Februari tahun 2010.
Tempat penelitian adalah di Laboratorium Dietetik Jurusan Gizi Kesehatan Fakultas Kedokteran Universitas Brawijaya dan Laboratorium Pengujian Mutu dan Keamanan Pangan Jurusan Teknologi Hasil Pertanian Universitas Brawijaya.

Populasi dan sampel adalah wortel organik varietas lokal (Cipanas) atau jenis imperator, yakni wortel yang memiliki umbi akar berukuran panjang dengan ujung meruncing, rasanya kurang manis (5), dan ditanam tanpa menggunakan pupuk kimia dan pestisida (6), siap panen berumur 85 hari, diameternya $\pm 1,5-3,5 \mathrm{~cm}$, ketebalan $\pm 0,5 \mathrm{~cm}$, bentuk potongan bulat-bulat, berat per biji lebih dari $100 \mathrm{~g}$, dan panjang per biji lebih dari $20 \mathrm{~cm}$, segar (maksimal setelah satu hari dipanen), bertekstur keras, berwarna oranye cerah, tidak ada cacat pada permukaan kulit, dan tidak ada kotoran pada permukaan kulitnya.

Sampel dipilih dengan cara quota sampling. Jumlah sampel yang digunakan dalam penelitian adalah 18 unit. Berat wortel masing-masing unit adalah $100 \mathrm{~g}$. Sampel diperoleh dari kebun organik yang berlokasi di Sukun.

Bahan yang digunakan dalam penelitian ini adalah bahan-bahan untuk pengolahan, yaitu: wortel, minyak kelapa sawit, dan air. Alat yang digunakan dalam penelitian ini adalah alat-alat untuk pengolahan, yaitu: timbangan skala, gelas ukur, panci, teflon, kompor, pisau, talenan, sendok, baskom, saringan, lap kain, kulkas, spon, penggaris, label nama. Bahan dan alat untuk analisis beta karoten didapatkan dari Laboratorium Pengujian Mutu dan Keamanan Pangan Jurusan Teknologi Hasil Pertanian Universitas Brawijaya.

Sampel wortel dibagi dalam 3 kelompok, yaitu wortel mentah, wortel perebusan, dan wortel 
penumisan. Masing-masing sampel dibawa ke laboratorium untuk diekstraksi beta karotennya dengan petroleum eter-aseton. Pemisahan pigmen dilakukan dengan kromatografi kolom dan pengukuran warna dilakukan dengan spektrofotometer pada panjang gelombang 450 $\mathrm{nm}$. Kandungan beta karoten dari tiap kelompok kemudian dibandingkan.

Pertama proses sortasi, wortel dipetik dan dipilih sesuai kriteria sebanyak $3,5 \mathrm{~kg}$ dari kebun. Dibawa pulang dengan dimasukkan ke dalam keranjang yang tertutup untuk menghindari radiasi matahari. Semua wortel dicuci dengan air bersih, ditiriskan lalu disimpan di kulkas pada suhu $4^{\circ} \mathrm{C}$ selama satu malam untuk menghambat kontaminasi sebelum dibawa ke laboratorium.

Semua wortel dikupas kulitnya lalu dipotong dengan bentuk bulat-bulat ketebalan $\pm 0,5 \mathrm{~cm}$ dan diameter $\pm 1,5-3,5 \mathrm{~cm}$. Potongan wortel dijadikan satu lalu diacak. Kemudian ditimbang $100 \mathrm{~g}$ per unit dan dijadikan 18 unit sampel.

Kemudian untuk persiapan wortel mentah, enam unit sampel masing-masing dimasukkan ke dalam kantung plastik tertutup, lalu disimpan ke dalam kulkas pada suhu $4^{\circ} \mathrm{C}$ untuk menghambat kontaminasi sebelum dianalisis.

Pada proses perebusan, satu unit sampel dimasukkan dalam $100 \mathrm{~mL}$ air mendidih pada suhu $100^{\circ} \mathrm{C}$, direbus selama 3 menit dengan api sedang, lalu diangkat dan ditiriskan selama 2 menit. Kemudian sampel dimasukkan ke dalam kantung plastik tertutup dan disimpan ke dalam kulkas pada suhu $4^{\circ} \mathrm{C}$ untuk menghambat kontaminasi sebelum dianalisis. Perlakuan diulang sebanyak 6 kali.

Pada proses penumisan, satu unit sampel dimasukkan dalam $10 \mathrm{~mL}$ minyak goreng baru yang sudah panas pada suhu $\pm 170^{\circ} \mathrm{C}$, lalu ditumis selama 3 menit dengan api sedang, diangkat, dan ditiriskan selama 2 menit. Sampel dimasukkan ke dalam kantung plastik tertutup dan disimpan ke dalam kulkas pada suhu $4^{\circ} \mathrm{C}$ untuk menghambat kontaminasi sebelum dianalisis. Alat-alat yang telah dipakaiDistribusi ke laboratorium, semua sampel dimasukkan ke dalam tas plastik hitam untuk menghindari radiasi matahari lalu dibawa ke Laboratorium Pengujian Mutu dan Keamanan
Pangan THP Universitas Brawijaya. Analisis beta karoten, setiap sampel dianalisis kandungan beta karotennya. Sampel diekstraksi dengan petroleum eter-aseton. Pemisahan pigmen secara kromatografi kolom dengan diukur warna pada panjang gelombang $450 \mathrm{~nm}$ di spektrofotometri. Perhitungan beta karoten, dibandingkan hasil kandungan beta karoten dari yang mentah. perebusan dengan air, dan penumisan dengan minyak goreng.

Data dianalisis dengan menggunakan uji statistik parametric test pada program komputer SPSS 14. Data yang diperoleh dari penelitian ini akan dianalisis melalui uji one way anova, posthoc tests duncan, paired t-test, dan independent t-test.

\section{HASIL}

Pengukuran kandungan beta karoten wortel pada tiap kelompok perlakuan menghasilkan ratarata kandungan beta karoten dari tiap kelompok perlakuan dapat dilihat pada Tabel 1.

Tabel 1 Rata-rata kandungan beta karoten wortel antarkelompok perlakuan $(\mu \mathrm{g} / \mathrm{g})$

\begin{tabular}{cc}
\hline Kelompok Perlakuan & Rata-rata \pm SD \\
\hline wortel mentah & $7,63 \pm 0,33^{\mathrm{a}}$ \\
wortel direbus & $7,23 \pm 0,23^{\mathrm{b}}$ \\
wortel ditumis & $7,10 \pm 0,26^{\mathrm{b}}$ \\
\hline
\end{tabular}

Keterangan :

a dan b merupakan notasi yang menunjukkan apabila notasinya berbeda berarti perbedaan signifikan.

Tabel 1 menunjukkan rata-rata beta karoten tertinggi pada kelompok wortel mentah sebesar 7,63 $\pm 0,33 \mu \mathrm{g} / \mathrm{g}$, sedangkan rata-rata beta karoten yang terendah pada kelompok wortel ditumis sebesar $7,10 \pm 0,26 \mu \mathrm{g} / \mathrm{g}$.

\section{BAHASAN}

Berdasarkan hasil uji statistik one way anova pada tingkat kepercayaan 95\% menunjukkan bahwa kandungan beta karoten antara tiga kelompok perlakuan berbeda signifikan yaitu $p=0,013$ ( $p<$ $0,05)$. Uji statistik lebih lanjut dengan menggunakan 
post hoc tests duncan menunjukkan bahwa terdapat perbedaan kandungan beta karoten yang signifikan antara kelompok (wortel mentah) dan kelompok perlakuan (wortel direbus dan wortel ditumis), antara wortel mentah dengan wortel direbus, antara wortel mentah dengan wortel ditumis. Walaupun demikian, tidak terdapat perbedaan kandungan beta karoten yang signifikan antara kelompok wortel direbus dengan wortel ditumis $(p>0,05)$.

Berdasarkan hasil uji statistik independent t-test pada tingkat kepercayaan $95 \%$ menunjukkan bahwa kandungan beta karoten antara kelompok wortel direbus dengan wortel ditumis tidak berbeda signifikan yaitu $p=0,376(p>0,05)$. Berdasarkan hasil uji statistik paired $t$-test pada tingkat kepercayaan 95\% menunjukkan bahwa kandungan beta karoten awal dan akhir dari teknik pengolahan perebusan menurun secara signifikan yaitu $p=0,027(p<0,05)$. Kandungan beta karoten awal dan akhir dari teknik pengolahan penumisan juga menurun secara signifikan yaitu $p=0,020(p<0,05)$.

Pada penelitian ini, batas suhu pemanasan tidak diukur dengan jelas sehingga tidak dapat menentukan suhu kerusakan beta karoten. Menurut Westport (7), minyak goreng akan mendidih pada suhu yang cukup tinggi yaitu $175-200^{\circ} \mathrm{C}$ (8), sedangkan suhu selama perebusan yaitu $100^{\circ} \mathrm{C}$ (9). Faktor dari titik didih minyak lebih tinggi daripada air, sifat minyak yang mengarah ke asam, serta kontak dengan logam dari sendok untuk menumis menyebabkan penurunan beta karoten setelah penumisan lebih tinggi dari perebusan (10), meskipun kandungan beta karoten tidak berbeda secara signifikan antara wortel yang ditumis dengan wortel yang direbus. Selain itu, pemanasan pada beta karoten menyebabkan beta karoten terisomerisasi dari bentuk trans ke cis sehingga menurunkan kandungan beta karotennya (11). Proses isomerisasi ini tidak disertai dengan perubahan warna sehingga menjadi kelemahan saat pengukuran kandungan beta karoten di spektrofotometri.

Adanya keterbatasan kemampuan cerna pada tubuh manusia, maka dianjurkan mengonsumsi wortel setelah pengolahan, yaitu dengan perebusan atau penumisan karena hasil penelitian menunjukkan kandungan beta karoten antara wortel direbus dengan ditumis tidak berbeda signifikan. Melalui perebusan dan penumisan, wortel dapat diolah dengan berbagai variasi masakan seperti sup dan cah/oseng-oseng yang selengkapnya dapat dilihat di resep-resep.

Hasil penelitian menunjukkan bahwa perebusan dan penumisan berpengaruh signifikan terhadap penurunan kandungan beta karoten dari wortel mentah. Solusi untuk menggunakan vitamin yang terlarut adalah dengan menggunakan air bekas rebusan dan minyak sisa tumisan wortel untuk memasak yang lain sehingga vitamin larut air dan beta karoten yang terlarut dalam minyak dapat digunakan secara optimal.

Beta karoten yang dikonsumsi oleh tubuh secara normal sebesar 3-6 mg per hari (12). Hasil penelitian menunjukkan dalam $1 \mathrm{~g}$ wortel terkandung beta karoten, maka untuk memenuhi kebutuhan $3 \mathrm{mg}$ beta karoten per hari setara dengan mengonsumsi $393 \mathrm{~g}$ wortel mentah, atau $415 \mathrm{~g}$ wortel yang direbus, atau $423 \mathrm{~g}$ wortel yand ditumis.

\section{KESIMPULAN DAN SARAN}

Proses pengolahan pada wortel baik dengan perebusan maupun penumisan dapat diterapkan keduanya karena kandungan beta karoten antara kedua jenis pengolahan tersebut tidak jauh berbeda. Kandungan beta karoten pada wortel direbus tidak berbeda secara signifikan dengan wortel ditumis yaitu $p=0,376(p>0,05)$.

Saran untuk penelitian selanjutnya antara lain: 1) perlu diadakan penelitian mengenai bioavaibilitas beta karoten wortel mentah, direbus, dan ditumis, 2) perbedaan suhu dan waktu pengolahan pada wortel, 3) perbedaan varietas dan luas permukaan pada wortel.

\section{RUJUKAN}

1. Almatsier S. Prinsip dasar ilmu gizi. Jakarta: Gramedia Pustaka Utama; 2003.

2. WHFoods. Wortel [Internet]. 2009. Available from: http://id.wikipedia.org/wiki/Wortel 
3. Gropper S, Smith J, JL G. Advanced nutrition and human metabolism. USA: Thomson Wadsworth; 2005.

4. Haris R, Karmas E. Evaluasi gizi pada pengolahan bahan pangan. Bandung: Penerbit ITB; 1989.

5. IPTEKnet. Tanaman obat Indonesia [Internet]. 2005. Available from: http://www.iptek.net.id/ ind/pd_tanobat/view.php?mnu=2\&id=150

6. Wikipedia. Organic farming [Internet]. 2010 [cited 2015 Sep 10]. Available from: http:// en.wikipedia.org/wiki/Organic_farming

7. Westport C. Basic food chemistry, 2nd edition. USA: The Avi Publishing Company, Inc; 1983.

8. Jarod R. Kripik buah [Internet]. 2007. Available from: http://www.usm.ac.id/fkk/?q=node/140
9. Miglio C, Chiavaro E, Visconti A, Fogliano $\mathrm{V}$, Pellegrini N. Effects of different cooking methods on nutritional and physicochemical characteristics of selected vegetables. J Agric Food Chem. 2008;56:143.

10. Eitenmiller R, Landen W, Lin Y. Vitamin analysis for health and food sciences. Florida: CRC Press; 2008.

11. Updike A, Schwartz S. Thermal processing of vegetables increases cis isomers of lutein and zeaxanthin. J Agric Food Chem Agric Food Chem. 2003;51(21):6184-90.

12. Astawan M. Terung Belanda si jagoan antioksidan [Internet]. 2008 [cited 2010 Jan 18]. Available from: http://cybermed.cbn.net.id/ cbprt//cybermed/detail.aspx? $\mathrm{x}=$ Natural+Healing $\& y=$ cybermed $\% 7 C 20 \% 7 C 0 \% 7 C 3 \% 7 C 157$ 